\title{
Colon cancer stem cell markers CD44 and CD133 in patients with colorectal cancer and synchronous hepatic metastases
}

\author{
FEIFENG JING $^{1}$, HUN JIN KIM ${ }^{1}$, CHANG HYUN KIM ${ }^{1}$, \\ YOUNG JIN KIM ${ }^{1}$, JAE HYUK LEE ${ }^{2}$ and HYEONG ROK KIM ${ }^{1}$ \\ Departments of ${ }^{1}$ Surgery and ${ }^{2}$ Pathology, Chonnam National University Medical \\ School and Hwasun Hospital, Gwangju, Republic of Korea \\ Received November 18, 2014; Accepted January 5, 2015
}

DOI: $10.3892 /$ ijo.2015.2844

\begin{abstract}
CD44 and CD133 mRNA expression as cancer stem cell markers in colorectal cancer were correlated with synchronous hepatic metastases and the clinicopathological factors, including patient survival. The CD44 and CD133 mRNA levels in 36 primary colorectal adenocarcinomas with synchronous hepatic metastasis were analyzed by reverse transcriptase polymerase chain reaction, with normalization relative to glyceraldehyde-3-phosphate dehydrogenase (GAPDH). Immunohistochemical analysis was performed on samples with typical mRNA expression patterns to investigate protein expression. Both CD44 and CD133 gene expressions were highest in hepatic metastasis tissue, followed by colorectal cancer and normal mucosa. The differences were statistically significant among groups of normal mucosa, colorectal cancer and hepatic metastasis tissue. CD44 mRNA expression was significantly associated with the tumor location $(\mathrm{P}=0.019)$ and histology $(\mathrm{P}=0.026)$. With a median follow-up period of 38 months, the 5-year disease-free survival rate of the patients with high CD44 mRNA expression in the CD44 hepatic metastasis tissue group was significantly lower than that of the patients with low expression $(\mathrm{P}=0.002)$. While the mRNA expressions in groups of CD44 colorectal tumor, CD133 colorectal tumor, and CD133 hepatic metastasis tissue were not significant. CD44 and CD133 mRNA were highly correlatively co-expressed in colorectal cancer with hepatic metastases. CD44 expression was an independent factor associated with patient survival, while CD133 did not show this pattern. Thus, CD44 is a more reliable marker for predicting hepatic metastases and survival. Larger prospective studies are required to confirm these findings.
\end{abstract}

Correspondence to: Dr Hyeong Rok Kim, Department of Surgery, Chonnam National University Hwasun Hospital and Medical School, 322 Seoyang-ro, Hwasun-eup, Hwasun-gun, Jeollanam-do 519-763, Republic of Korea

E-mail:drkhr@jnu.ac.kr

Key words: CD44, CD133, cancer stem cell markers, colorectal carcinoma, hepatic metastasis

\section{Introduction}

Colorectal cancer (CRC) is one of the most common malignancies in the world and a major cause of mortality (1). At the time of diagnosis, $\sim 50 \%$ of patients presented with liver metastasis, with $20-25 \%$ of these presenting with synchronous liver metastases (2). Combinations of chemotherapy and biological therapy have improved disease-free survival for patients with metastatic CRC (3). Lesions that underwent curative resection have demonstrated 5-year survival exceeding 50\% (4). However, there are still disappointingly high rates of local recurrence or distant metastasis after curative surgical resection (5). Thus, the early detection of liver metastasis becomes increasingly desirable for patient survival. The cancer stem cell (CSC) theory presumes that solid tumor initiation, maintenance, and progression are the result of a small population of cancer cells with self-renewal and pluripotency capabilities (6). This population of cells is often considered to be associated with chemoresistance and radioresistance that lead to the failure of traditional therapy $(7,8)$. A better understanding of CSCs will allow us to detect remote metastasis earlier, target CSC subpopulations and potentially eradicate tumors $(5,9)$. Identifying the molecular markers of a metastatic phenotype is a prerequisite for developing new therapeutic approaches in CRC (10,11).

CD44, a transmembrane glycoprotein that serves as a recyclable receptor for hyaluronan, plays important roles in regulating cell adhesion, proliferation, growth, survival, motility, migration, angiogenesis and differentiation $(12,13)$. The CD44 marker can be used to isolate CSC populations from colorectal tumors (14). Furthermore, CD44 has been demonstrated to perform an unexpected tumor-progressing function and lead to tumor metastasis, resulting in worse prognosis (15).

CD133 (also known as Prominin-1 or AC133), a cell surface transmembrane glycoprotein, was identified in subpopulations of cells in colon tumors (16). Subpopulations of CD133-positive colon cancer cells have shown increased tumorigenic potential in transplantation studies in vitro and in vivo (16-18). Moreover, high expression of CD133 is associated with poor prognosis, resistance to chemotherapy $(19,20)$ and radiotherapy $(21)$ and even distant metastasis $(22,23)$. Recently, some studies have focused on CD44 and CD133 co-expression. Cells from 
Table I. Primer sequences used for RT-PCR.

\begin{tabular}{|c|c|c|c|}
\hline & Primer (5'-3', forward/reverse) & $\begin{array}{c}\text { PCR } \\
\text { conditions } \mathrm{s}^{\mathrm{a}}\end{array}$ & $\begin{array}{l}\text { Product } \\
\text { size (bp) }\end{array}$ \\
\hline CD44 & CTGCAGGTATGGGTTCATAG/ATATGTGTCATACTGGGAGGTG & $60(35)$ & 124 \\
\hline CD133 & GATTAAGTCCATGGCAACAGCG/GCTGGTCAGACTGCTGCTAAGC & $60(35)$ & 115 \\
\hline GAPDH & ACGGGAAGCTTGTCATCAATGG/ATGGTGGTGAAGACGCCAGTGG & $60(35)$ & 124 \\
\hline
\end{tabular}

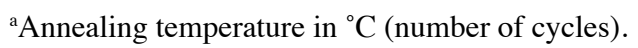

peritoneal washes of metastatic colon cancer patients or the metastatic colon cancer HCT116 cell line positively express CD44 and CD133 (24). CD133 ${ }^{+} \mathrm{CD} 44^{+}$cells are undifferentiated, with the abilities of extensive self-renewal and epithelial lineage differentiation in vitro $(13,25,26)$. Moreover, long-term cultured $\mathrm{CD} 133^{+} \mathrm{CD} 44^{+}$cells can enrich a CD $133^{+} \mathrm{CD} 44^{\text {high }}$ subpopulation of cells that express epithelial to mesenchymal transition marker, are more invasive in vitro, and are responsible for liver metastasis in vivo (26). Other studies revealed that CD44 and CD133 co-expression is significantly higher in colon cancers with early liver metastases than in those without early liver metastases $(4,5)$, and overall survival of patients who are positive for both CD44 and CD133 is significantly shorter than that of all other patients (27). A recent study directly verified the momentous role of $\mathrm{CD} 133^{+} \mathrm{CD} 44^{+}$tumor cells in hematogenous metastasis of liver cancers, suggesting that CD133 is important for tumor growth and CD44 is responsible for invasion. CD133 and CD44 can be regarded as cooperative markers of liver metastasis-facilitating pathways (28). In another study, Bellizzi et al (29) generated stem cell enriched human colonosphere cultures from fresh samples and compared the sphere-forming potential of these clones. $\mathrm{CD}_{133^{+}}$colon cancer cells were confirmed to play a crucial role both in primary tumors and in metastatic lesions, but liver metastasis seemed to be strictly related to $\mathrm{CD} 133^{+} \mathrm{CD} 44^{+}$.

CD44 and CD133 appear to be useful markers for isolation and further characterization of colorectal CSCs. However, the relationships among expression of colon CSC markers, CRC metastasis, and clinicopathological features are still unknown. Moreover, there have been few studies focusing on mRNA expression using simple and practical methods such as reverse transcription polymerase chain reaction (RT-PCR). The aim of the present study was to examine CD44 and CD133 mRNA expression in CRC and analyze the potential correlation with hepatic metastasis and clinicopathological factors.

\section{Materials and methods}

Tissue samples. Tissue samples were obtained from 36 patients diagnosed with primary CRC with synchronous hepatic metastasis from 2004 to 2011 in the Department of Colorectal Surgery, Chonnam National University Hwasun Hospital, South Korea.

RNA extraction. One of the successive tissue slides was stained with hematoxylin and eosin, and two pathologists measured and circled the areas of normal mucosa, CRC, and hepatic metastasis to indicate the associated normal or tumor tissue area. Other slides were used for RNA isolation after removing irrelevant tissue. The slides were dewaxed in xylene, rinsed in a graded ethanol series, and finally rehydrated in double-distilled water. The tissue was scraped into a $1.5-\mathrm{ml}$ microcentrifuge tube. The total RNA was isolated using TRIzol ${ }^{\circledR}$ reagent (Invitrogen, Carlsbad, CA, USA) according to the manufacturer's protocol. After 10-min incubation at room temperature, RNA was extracted by the addition of $200 \mu \mathrm{l}$ chloroform (Sigma, St. Louis, MO, USA). The tube was lightly shaken for $15 \mathrm{sec}$ and then incubated for $10 \mathrm{~min}$. The phases were separated automatically, followed by a 15 -min centrifugation at $13,000 \mathrm{rpm}$ in a table-top centrifuge at $4^{\circ} \mathrm{C}$. The aqueous phase was transferred to a fresh tube, and an equal volume of isopropanol (Fisher Scientific, Seoul, Korea) was added. The mixture was incubated at room temperature for $10 \mathrm{~min}$ to precipitate RNA. After another 15-min centrifugation at 13,000 rpm and $4^{\circ} \mathrm{C}$, the supernatant was carefully discarded. One milliliter of $80 \%$ ethanol was added to the tube, which was then centrifuged at $4^{\circ} \mathrm{C}$ for $5 \mathrm{~min}$ at 7,500 rpm. After the liquid had been discarded, the content of the tube was dried briefly for $\sim 15 \mathrm{~min}$ at room temperature without centrifugation. The RNA pellet was dissolved in $15 \mu \mathrm{l}$ of diethylpyrocarbonate-treated water (Biosesang, Seongnam, Korea), and the RNA was quantified using a NanoDrop ${ }^{\text {TM }}$ ND-1000 spectrophotometer (NanoDrop Technologies, Wilmington, DE, USA) at $260 \mathrm{~nm}$.

cDNA synthesis. Reverse transcription was performed using the Moloney murine leukemia virus reverse transcriptase (M-MLV RT; Beams Biotech, Seongnam, Korea). Each total RNA template $(2 \mu \mathrm{g})$ was reverse transcribed with mixture of $0.25 \mu \mathrm{g}$ oligo(dT) primer and $0.5 \mu \mathrm{g}$ random primers (Promega, Seoul, Korea). The sample tube was heated to $72^{\circ} \mathrm{C}$ for $10 \mathrm{~min}$, chilled rapidly on ice, and then spun briefly to collect the solution at the bottom of the tube. Then $0.5 \mu \mathrm{l}$ ribonuclease inhibitor (40 U/ $\mu \mathrm{l}$; Beams Biotech), $1 \mathrm{X} \mathrm{M}-\mathrm{MLV}$ reaction buffer, $10 \mathrm{mM}$ dNTPs, and $0.5 \mu \mathrm{l} \mathrm{M-MLV} \mathrm{RT} \mathrm{(200} \mathrm{U/} \mu 1$; Beams Biotech) were added, and the mixture was incubated for $70 \mathrm{~min}$ at $42^{\circ} \mathrm{C}$ and $10 \mathrm{~min}$ at $72^{\circ} \mathrm{C}$.

$R T-P C R$. RT-PCR was performed using nTaq-HOT DNA polymerase (Enzynomics, Seoul, Korea). Oligonucleotide primers specific for CD44, CD133 and GAPDH were designed from their GenBank sequences (AJ251595.1, NM_006017.2 and NM_002046.3, respectively). The GAPDH gene was used as an internal control. The PCR primer sequences are listed in Table I. The RT-PCR products were electrophoresed through 
a $4 \%$ agarose gel at $100 \mathrm{~V}$ for $25 \mathrm{~min}$ in $1 \mathrm{X}$ TBE buffer. After being stained with ethidium bromide $(5 \mathrm{mg} / \mathrm{ml})$, the gels were photographed under ultraviolet light. The RT-PCR products were quantified using an Image Reader (Mulit Gauge2.0 Analytical Software; FujiFilm, Tokyo, Japan).

Immunohistochemistry. Immunohistochemical staining was performed on specimens that showed a typical mRNA expression pattern. Sections of formalin-fixed, paraffin-embedded tissues of CRC, synchronous hepatic metastasis tissue, and the adjacent normal mucosa were sliced into $3-\mu \mathrm{m}$-thick sections and mounted on silane-coated glass slides. The slides were dewaxed in xylene, and rehydrated in a graded ethanol series followed by double-distilled water. For antigen retrieval, slides for CD44 and CD133 were treated by pressure cooker for $15 \mathrm{~min}$ in sodium citrate buffer $(10 \mathrm{mM}$, pH 6.0; Sigma-Aldrich, Bangalore, India) and retrieval buffer ( $\mathrm{pH}$ 9.0; Dako, Carpinteria, CA, USA), respectively. Specimens were rinsed and blocked with $3 \% \mathrm{H}_{2} \mathrm{O}_{2}$ for 10 min to abolish endogenous peroxidase activity. To reduce non-specific background staining, 5\% normal goat serum was placed on the sections for $1 \mathrm{~h}$ at room temperature, and then drained off. Finally, the sections were incubated overnight at $4^{\circ} \mathrm{C}$ with the CD44 monoclonal antibody (Cell Signaling Technology, Danvers, MA, USA) and AC133 monoclonal antibody (Miltenyi Biotec $\mathrm{GmbH}$, Bergisch Gladbach, Germany), respectively, both at a dilution of 1:100. The slides were washed three times with $1 \mathrm{X}$ TBS-T, followed by incubations for $1 \mathrm{~h}$ with HRP (Cell Signaling Technologies) and polymer HRP anti-rabbit and mouse IgG (Life Technologies, Grand Island, NY, USA), respectively. Immunostaining was visualized using 3,3'-diaminobenzidine (DAB) (Dako). All the slides were counterstained with hematoxylin, dehydrated and mounted. The negative control was performed by incubating samples with $1 \mathrm{X}$ TBS-T (data not shown). All the sections were independently examined for their protein expressions and assessed by comparing the staining among the normal mucosa, CRC, and hepatic metastasis regions under microscopic examination. All the histological slides were examined by two experienced gastrointestinal pathologists who were unaware of the clinical data or disease outcomes.

Statistical analysis. All statistical analyses were performed with SPSS version 17.0 (SPSS Inc., Chicago, IL, USA). The associations between the mRNA expression of CD44 and CD133 and the clinicopathological parameters were examined using the Chi-squared test. To evaluate the associations with disease-free survival, the median normalized CD44 and CD133 value (metastasis/normal, 1.25 and 1.22 , respectively) was chosen as the cut-off point for discriminating the 36 patients into two subgroups (low vs. high). The Kaplan-Meier method was used to estimate survival as a function of time, and survival differences were assessed with the log-rank test. A value of $\mathrm{P}<0.05$ was considered statistically significant.

\section{Results}

Typical results of gene expression by reverse transcriptase polymerase chain reaction are shown in Fig. 1. The mean \pm SD intensities of CD44 gene expression with ratio of GAPDH in

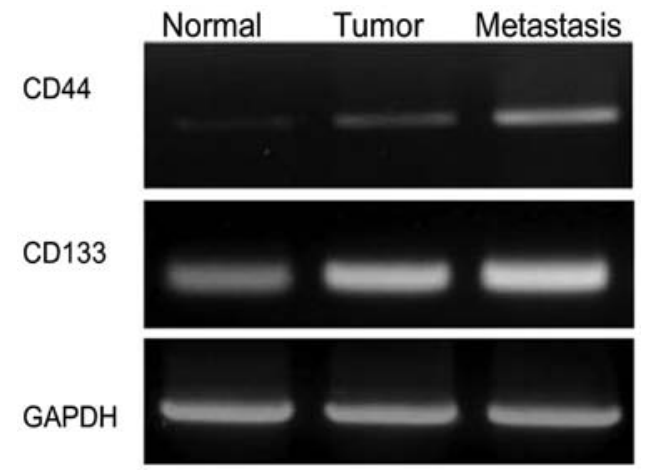

Figure 1. CD44 and CD133 gene expressions in colorectal cancer, corresponding synchronous hepatic metastasis tissue and normal mucosa by reverse transcription PCR.
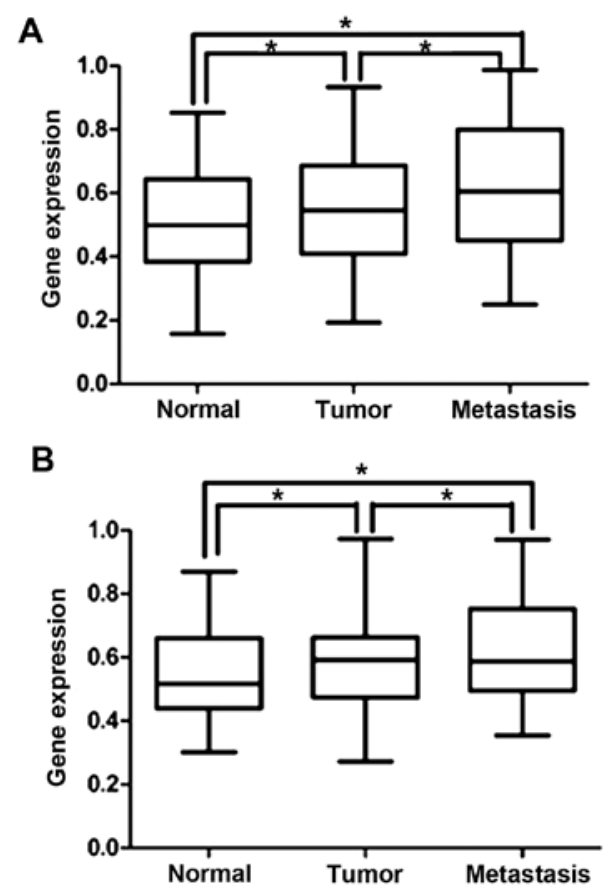

Figure 2. Quantitative CD44 and CD133 mRNA expression from colorectal cancer, corresponding synchronous hepatic metastasis tissue and normal mucosa by reverse transcription PCR. Relative values were normalized to GAPDH ( $\left.{ }^{*} \mathrm{P}<0.05\right)$. (A) CD44 expression; (B) CD133 expression.

enrolled 36 samples were $0.5443 \pm 0.1955$ in colorectal tumor, $0.6226 \pm 0.2037$ in hepatic metastasis tissue, and $0.5081 \pm 0.1882$ in adjacent normal tissue. For CD133 gene expression, mean intensities were $0.5889 \pm 0.1564$ in colorectal tumor, $0.6354 \pm 0.1696$ in hepatic metastasis tissue and $0.5396 \pm 0.1356$ in adjacent normal tissue.

mRNA expression. The CD44 expression in the groups was statistically different between normal tissue and colorectal tumor $(\mathrm{P}=0.008)$, between normal tissue and hepatic metastasis tissue $(\mathrm{P}<0.001)$ and between colorectal tumor and hepatic metastasis tissue $(\mathrm{P}<0.001)$. CD133 expression was also significantly different between normal tissue and colorectal tumor $(\mathrm{P}=0.024)$, between normal tissue and hepatic metastasis tissue $(\mathrm{P}<0.001)$, and between colorectal tumor and hepatic metastasis tissue ( $\mathrm{P}=0.040)$ (Fig. 2). 
Table II. Correlation between mRNA expression of CD44 and CD133 and the clinicopathological parameters of colorectal cancer metastasis.

\begin{tabular}{|c|c|c|c|c|c|c|c|}
\hline \multirow[b]{2}{*}{ Parameters } & \multirow[b]{2}{*}{ No. } & \multicolumn{2}{|c|}{ CD44 expression } & \multirow[b]{2}{*}{ P-value } & \multicolumn{2}{|c|}{ CD133 expression } & \multirow[b]{2}{*}{ P-value } \\
\hline & & Low $(\mathrm{n}=20)$ & $\operatorname{High}(n=16)$ & & Low $(n=27)$ & High (n=9) & \\
\hline \multicolumn{8}{|l|}{ Age (years) } \\
\hline$\leq 60$ & 15 & 7 & 8 & 0.500 & 11 & 4 & 1.000 \\
\hline$>60$ & 21 & 13 & 8 & & 16 & 5 & \\
\hline \multicolumn{8}{|l|}{ Gender } \\
\hline Male & 21 & 11 & 10 & 0.741 & 16 & 5 & 1.000 \\
\hline Female & 15 & 9 & 6 & & 11 & 4 & \\
\hline \multicolumn{8}{|l|}{ Tumor location } \\
\hline Colon & 21 & 8 & 13 & 0.019 & 16 & 5 & 1.000 \\
\hline Rectum & 15 & 13 & 3 & & 11 & 4 & \\
\hline \multicolumn{8}{|l|}{ Histology } \\
\hline Well + moderate & 20 & 15 & 5 & 0.026 & 17 & 3 & 0.202 \\
\hline Poor & 15 & 5 & 10 & & 9 & 6 & \\
\hline \multicolumn{8}{|l|}{ Tumor size } \\
\hline$\leq 5$ & 21 & 13 & 8 & 0.500 & 14 & 7 & 0.252 \\
\hline$>5$ & 15 & 7 & 8 & & 13 & 2 & \\
\hline \multicolumn{8}{|c|}{ Depth of invasion (T) } \\
\hline $\mathrm{T} 1+\mathrm{T} 2$ & 32 & 17 & 15 & 0.613 & 24 & 8 & 1.000 \\
\hline $\mathrm{T} 3+\mathrm{T} 4$ & 4 & 3 & 1 & & 3 & 1 & \\
\hline \multicolumn{8}{|c|}{ Lymphovascular invasion } \\
\hline Negative & 28 & 17 & 11 & 0.422 & 20 & 8 & 0.648 \\
\hline Positive & 8 & 3 & 5 & & 7 & 1 & \\
\hline \multicolumn{8}{|l|}{ Perineural invasion } \\
\hline Negative & 22 & 13 & 9 & 0.734 & 17 & 5 & 0.712 \\
\hline Positive & 14 & 7 & 7 & & 10 & 4 & \\
\hline \multicolumn{8}{|c|}{ Preoperative CEA (ng/ml) } \\
\hline$\leq 5$ & 17 & 10 & 7 & 0.749 & 11 & 6 & 0.255 \\
\hline$>5$ & 19 & 10 & 9 & & 16 & 3 & \\
\hline
\end{tabular}

Immunohistochemistry. To investigate expression of CD44 and CD133 proteins, immunohistochemical analysis was performed on samples with typical mRNA expression patterns. Consistent with previous reports $(22,30-32)$, the CD44 and CD133 immunoreactivities were visualized as brown membrane and lumina surface staining, respectively (Fig. 3). Hepatic metastasis tissue exhibited the highest expression of CD44 and CD133 proteins, followed by CRC and normal mucosa, consistent with previous reports.

Clincopathological parameters. This analysis included tissue samples from 21 (58\%) male patients and 15 (42\%) female patients with a median age of 66 years (range, $42-91$ years). Twenty-one (58\%) tumors were located in the colon, and 15 $(42 \%)$ were in the rectum. The median tumor size was $4.6 \mathrm{~cm}$ (range, 1.5-8.5 cm). The relations between CD44 and CD133 mRNA expression and the clinicopathological factors are shown in Table II. Tumors in colon and poorly differentiated tumors showed high CD44 mRNA expression with statistical significance. However, there were no significant differences in CD44 and CD133 mRNA expression according to age, gender, tumor size, depth of invasion, lymphovascular invasion, perineural invasion or preoperative CEA level.

Prognosis. With a median follow-up period of 38 months, the 5-year disease-free survival of the patients with high CD44 mRNA expression in CD44 hepatic metastasis tissue was significantly lower than that of the patients with low expression ( $\mathrm{P}=0.002$; Fig. 4). The mRNA expressions of $\mathrm{CD} 44$ in colorectal tumor, CD133 in colorectal tumor, and CD133 in hepatic metastasis tissue were not significantly associated with survival.

\section{Discussion}

The CSC theory has significant implications in cancer therapy. CSCs, which are characterized by a slow cell cycle, have been reported to be resistant to anticancer therapies by intrinsic 

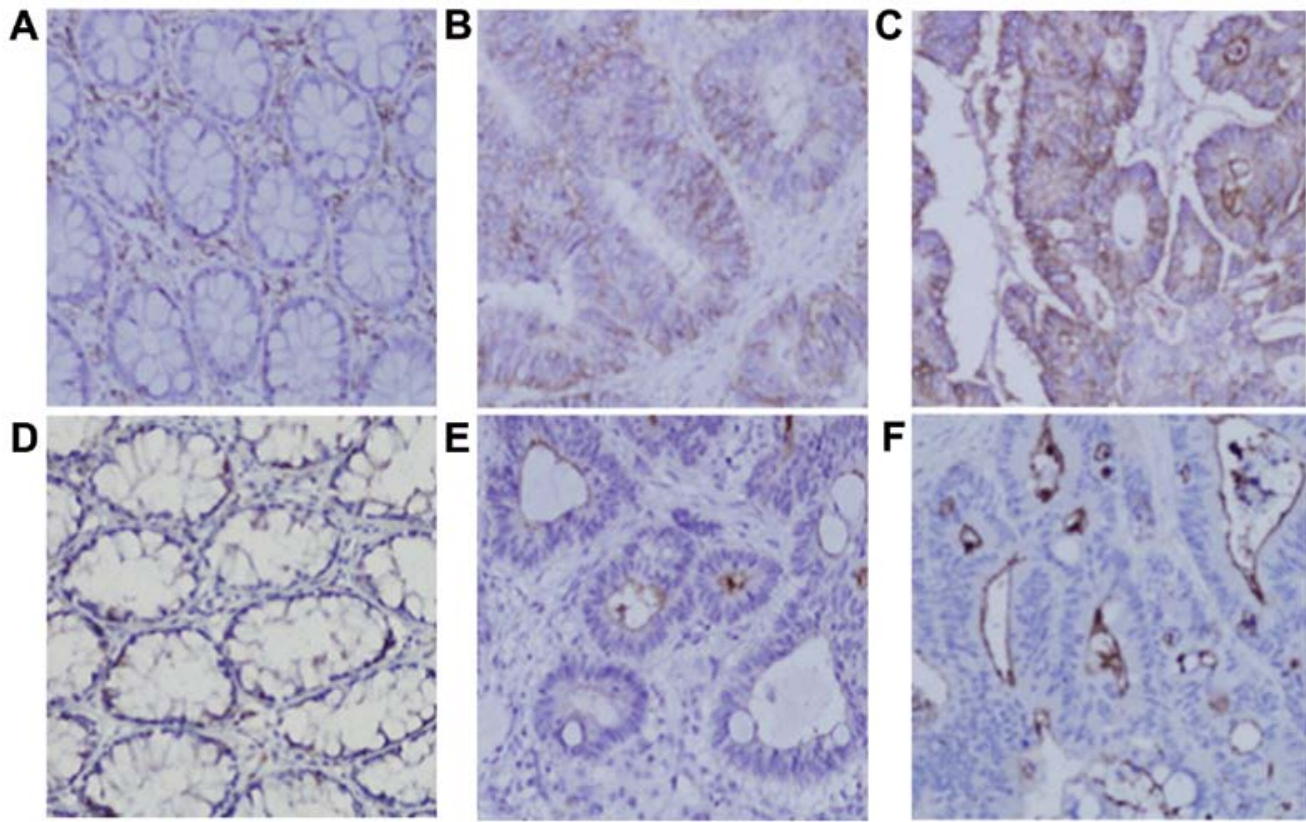

Figure 3. Immunohistochemical staining of CD44 and CD133 staining in normal mucosa (A and D), colorectal cancer (B and E) and synchronous hepatic metastases tissue (C and F). Magnification, x200.
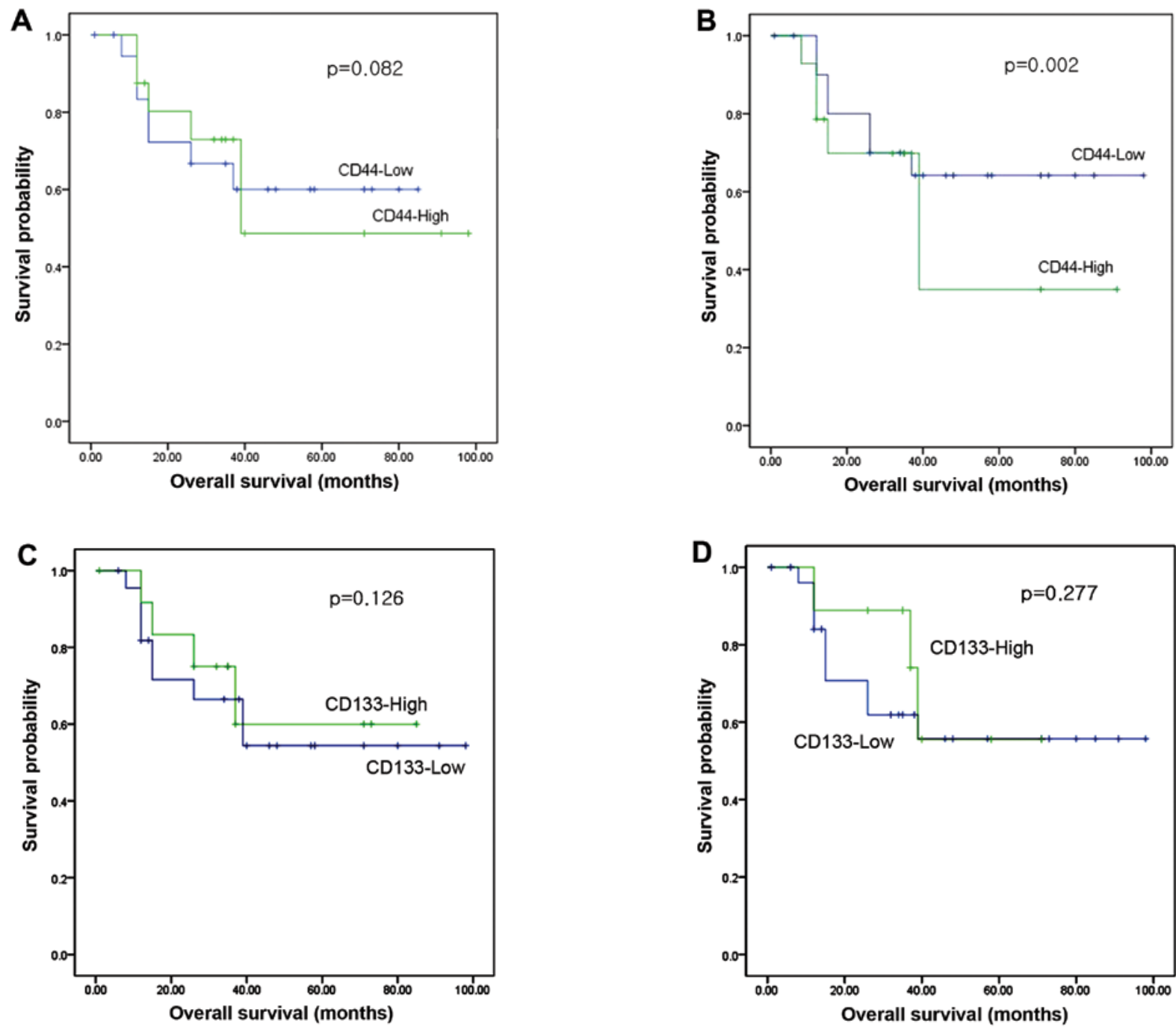

Figure 4. Survival curves according to CD44 and CD133 mRNA expressions in groups of colorectal cancer and synchronous hepatic metastases tissue (n=36). (A) CD44 expression in colorectal cancer; (B) CD44 expression in liver metastasis; (C) CD133 expressions in colorectal cancer; (D) CD133 expression in liver metastasis. 
defense mechanisms, such as quiescence, efflux pumps, and detoxifying enzymes, and by induction of anti-apoptotic proteins $(5,33,34)$. The result is that conventional cytotoxic therapies initially shrink the bulk of a tumor but fail to eradicate it, resulting in tumor recurrence, because current chemotherapeutics interfere with the ability of rapidly growing cells and, therefore, might spare CSCs $(35,36)$. Treatment approaches that target CSCs may increase the efficacy of current treatment regimens and reduce the risk of tumor relapse and metastasis (37).

One of the major findings of the present study is that CD44 and CD133 mRNA were more highly co-expressed in hepatic metastases tissue than in CRC and normal tissue, which is consistent with other evidence, such as protein expression (11), suggesting that CD44 and CD133 might be potential biomarkers for predicting liver metastases of CRC. Even though the underlying mechanism of CD44 and CD133 co-expression is unknown, studies of their co-expression in protein and mRNA levels are reliable $(4,26,29)$. Moreover, one study demonstrated the critical role of $\mathrm{CD} 133{ }^{+} \mathrm{CD} 44^{+}$tumor cells in hematogenous metastasis of liver cancers, suggesting that CD133 is responsible for tumor growth and CD44 is important for invasion, two important factors in tumor metastasis (28).

CD44 mRNA expression in the liver metastasis tissue group showed statistically significant association with colon tumors $(\mathrm{P}=0.019)$ and poorly differentiated tumors $(\mathrm{P}=0.026)$, but not with rectal tumors and well and moderately differentiated tumors. The difference in results from colon and rectal tumors might be due to embryologic, morphologic, physiologic, histochemical and biological differences between colon cancer and rectal cancer (38). The difference in results between poorly differentiated and well and moderately differentiated tumors is inconsistent with reports that poorly differentiated CRC is responsible for more extensive invasiveness (39) and poorer prognosis (40), and might be associated with more frequent microsatellite instability, a cause of genomic instability (41).

The evidence regarding the use of currently known colon CSC markers as prognostic indicators is contradictory. In the present study, disease-free survival of the patients with high CD44 mRNA expression in the liver metastasis tissue group was significantly lower than that of patients with low expression, but the CRC groups did not show a similar pattern. Expression of CD44 is associated with worse outcome for CRC patients. Mulder et al (42) reported that increased CD44 expression is associated with increased tumor-related death. However, some studies failed to detect a relationship between CD44 expression and patient outcome or tumor progression $(22,43)$. Notably, less membranous CD44 has been linked to worse survival and remote metastasis in other studies $(11,44)$.

For CD133, Horst et al (45) found that increased CD133 expression assessed by immunohistochemistry is associated with worse outcome. They also compared the prognostic value of colon CSC markers CD133, CD44 and CD166 in CRC. CD133 turned out to be the best prognostic marker and indicated significantly worse prognosis $(22,27)$. In another study, CD133 expression was associated with worse outcome when comparing well and moderately differentiated cancer (46). In addition, CD133 expression increased in stage IIIB colon cancer samples, indicative of worse outcome (47). In contrast, Choi et al (48) discovered that none of the colon CSC markers CD133, CD44 or CD24 were significant prognostic predictors of survival. Furthermore, Lugli et al (44), using tissue microarrays, failed to demonstrate an association between CD133 expression and tumor progression or patient survival.

In the present study, consistent with previous results, we found that CD133 mRNA expression in colorectal tumor and liver metastasis tissue was not significantly associated with disease-free survival. There are large disparities in the reported prognostic potential of colon CSC markers. The different results among the groups could be explained by the varied methods and cut-offs used in tissue staining and scoring $(49,50)$. Moreover, this study had some limitations. First, the number of samples in this study was not large, allowing the possibility of a type II error. Second, CD44 and CD133 mRNA expression level was analyzed by RT-PCR with 35 cycles, which may be slightly too many cycles, since formalin-fixed, paraffin-embedded tumor specimens were used (49). Galizia et al (5) demonstrated the critical role of CD44 and CD133 co-expression by fluorescence-activated cell sorting, which is a complex and time-consuming method. In the present study, we used much simpler techniques (RT-PCR and immunohistochemistry), which might be clinically promising to perform. Although our findings were insufficient to draw definite conclusions, further investigations with more samples may demonstrate associations between expression of the CSC markers CD44 and CD133, liver metastasis and clinicopathological parameters.

In conclusion, CD44 and CD133 mRNA were highly co-expressed in CRC with hepatic metastases. CD44 expression was an independent factor associated with patient survival, while CD133 did not show this pattern. Thus, CD44 is a more reliable marker for predicting hepatic metastases and survival. Further prospective controlled studies with larger numbers are warranted to support these findings.

\section{Acknowledgements}

The present study was supported by Chonnam National University, 2012-2684 and Research Grant 0720570 from the National Cancer Center and by a Grant from the Chonnam National Univeristy Biomedical Research Institute (CRI 13042-21, 22), South Korea.

\section{References}

1. Siegel R, Naishadham D and Jemal A: Cancer statistics, 2012. CA Cancer J Clin 62: 10-29, 2012.

2. Sakai Y: Current topics in colorectal liver metastasis. Int J Clin Oncol 16: 451-451, 2011.

3. Van Cutsem E, Lambrechts D, Prenen H, Jain RK and Carmeliet P: Lessons from the adjuvant bevacizumab trial on colon cancer: what next? J Clin Oncol 29: 1-4, 2011.

4. Huang X, Sheng Y and Guan M: Co-expression of stem cell genes CD133 and CD44 in colorectal cancers with early liver metastasis. Surg Oncol 21: 103-107, 2012.

5. Galizia G, Gemei M, Del Vecchio L, et al: Combined CD133/ CD44 expression as a prognostic indicator of disease-free survival in patients with colorectal cancer. Arch Surg 147: 18-24, 2012.

6. Anderson EC, Hessman C, Levin TG, Monroe MM and Wong MH: The role of colorectal cancer stem cells in metastatic disease and therapeutic response. Cancers (Basel) 3: 319-339, 2011. 
7. $\mathrm{Hu} \mathrm{Y}$ and $\mathrm{Fu} \mathrm{L}$ : Targeting cancer stem cells: a new therapy to cure cancer patients. Am J Cancer Res 2: 340-356, 2012.

8. Yu ZR, Pestell TG, Lisanti MP and Pestell RG: Cancer stem cells. Int J Biochem Cell Biol 44: 2144-2151, 2012

9. Soltanian S and Matin MM: Cancer stem cells and cancer therapy. Tumour Biol 32: 425-440, 2011.

10. Wakamatsu Y, Sakamoto N, Oo HZ, Naito Y, Uraoka N, Anami K, Sentani K, Oue N and Yasui W: Expression of cancer stem cell markers ALDH1, CD44 and CD133 in primary tumor and lymph node metastasis of gastric cancer. Pathol Int 62: 112-119, 2012.

11. Bendardaf R, Algars A, Elzagheid A, Korkeila E, Ristamaki R, Lamlum H, Collan Y, Syrjanen K and Pyrhonen S: Comparison of CD44 expression in primary tumours and metastases of colorectal cancer. Oncol Rep 16: 741-746, 2006.

12. Bird NC, Mangnall D and Majeed AW: Biology of colorectal liver metastases: a review. J Surg Oncol 94: 68-80, 2006.

13. Jaggupilli A and Elkord E: Significance of CD44 and CD24 as cancer stem cell markers: an enduring ambiguity. Clin Dev Immunol: May 30, 2012. doi: 10.1155/2012/708036.

14. Dalerba P, Dylla SJ, Park IK, et al: Phenotypic characterization of human colorectal cancer stem cells. Proc Natl Acad Sci USA 104: 10158-10163, 2012.

15. Su YJ, Lai HM, Chang YW, Chen GY and Lee JL: Direct reprogramming of stem cell properties in colon cancer cells by CD44 EMBO J 30: 3186-3199, 2011.

16. Ricci-Vitiani L, Lombardi DG, Pilozzi E, Biffoni M, Todaro M, Peschle $C$ and De Maria R: Identification and expansion of human colon cancer-initiating cells. Nature 445: 111-115, 2007.

17. Haraguchi N, Ohkuma M, Sakashita H, Matsuzaki S, Tanaka F, Mimori K, Kamohara Y, Inoue $\mathrm{H}$ and Mori M: CD133 ${ }^{+} \mathrm{CD} 44^{+}$ population efficiently enriches colon cancer initiating cells. Ann Surg Oncol 15: 2927-2933, 2008.

18. O'Brien CA, Pollett A, Gallinger S and Dick JE: A human colon cancer cell capable of initiating tumour growth in immunodeficient mice. Nature 445: 106-110, 2007.

19. Bao SD, Wu QL, McLendon RE, Hao YL, Shi Q, Hjelmeland AB Dewhirst MW, Bigner DD and Rich JN: Glioma stem cells promote radioresistance by preferential activation of the DNA damage response. Nature 444: 756-760, 2006.

20. Frank NY, Pendse SS, Lapchak PH, Margaryan A, Shlain D, Doeing C, Sayegh MH and Frank MH: Regulation of progenitor cell fusion by ABCB5 P-glycoprotein, a novel human ATP-binding cassette transporter. J Biol Chem 278: 47156-47165, 2003

21. Frank NY, Margaryan A, Huang Y, Schatton T, WaagaGasser AM, Gasser M, Sayegh MH, Sadee W and Frank MH: ABCB5-mediated doxorubicin transport and chemoresistance in human malignant melanoma. Cancer Res 65: 4320-4333, 2005.

22. Horst D, Kriegl L, Engel J, Kirchner T and Jung A: Prognostic significance of the cancer stem cell markers CD133, CD44, and CD166 in colorectal cancer. Cancer Invest 27: 844-850, 2009.

23. Saigusa S, Tanaka K, Toiyama Y, Yokoe T, Okugawa Y, Ioue Y, Miki C and Kusunoki M: Correlation of CD133, OCT4, and SOX2 in rectal cancer and their association with distant recurrence after chemoradiotherapy. Ann Surg Oncol 16: 3488-3498, 2009.

24. Botchkina IL, Rowehl RA, Rivadeneira DE, Karpeh MS Jr, Crawford H, Dufour A, Ju J, Wang Y, Leyfman Y and Botchkina GI: Phenotypic subpopulations of metastatic colon cancer stem cells: genomic analysis. Cancer Genomics Proteomics 6: 19-29, 2009.

25. Botchkina GI, Zuniga ES, Das M, el al: New-generation taxoid SB-T-1214 inhibits stem cell-related gene expression in 3D cancer spheroids induced by purified colon tumor-initiating cells. Mol Cancer 9: 192, 2010. doi: 10.1186/1476-4598-9-192.

26. Chen KL, Pan F, Jiang H, Chen JF, Pei L, Xie FW and Liang HJ: Highly enriched CD133(+)CD44(+) stem-like cells with CD133(+) CD44(high) metastatic subset in HCT116 colon cancer cells. Clin Exp Metastasis 28: 751-763, 2011.

27. Nagata T, Sakakura C, Komiyama S, et al: Expression of cancer stem cell markers CD133 and CD44 in locoregional recurrence of rectal cancer. Anticancer Res 31: 495-500, 2011.

28. Hou Y, Zou QF, Ge RL, Shen F and Wang YZ: The critical role of $\mathrm{CD}_{133}{ }^{+} \mathrm{CD} 44^{+/ \text {high }}$ tumor cells in hematogenous metastasis of liver cancers. Cell Res 22: 259-272, 2012.

29. Bellizzi A, Sebastian S, Ceglia P, et al: Co-expression of $\mathrm{CD}_{133^{+}}$ $\mathrm{CD} 44^{+}$in human colon cancer and liver metastasis. J Cell Physiol 228: 408-415, 2013.
30. Huh JW, Kim HR, Kim YJ, Lee JH, Park YS, Cho SH and Joo JK: Expression of standard CD44 in human colorectal carcinoma: association with prognosis. Pathol Int 59: 241-246, 2009.

31. Ohji Y, Yao T, Eguchi T, Yamada T, Hirahashi M, Iida M and Tsuneyoshi M: Evaluation of risk of liver metastasis in colorectal adenocarcinoma based on the combination of risk factors including CD10 expression: Multivariate analysis of clinicopathological and mmunohistochemical factors. Oncol Rep 17: 525-530, 2007.

32. Park JJ, Kwon JH, Oh SH, et al: Differential expression of CD133 based on microsatellite instability status in human colorectal cancer. Mol Carcinog 53: E1-E10, 2014.

33. Jones RJ: Cancer stem cells - clinical relevance. J Mol Med (Berl) 87: 1105-1110, 2009

34. Papailiou J, Bramis KJ, Gazouli M and Theodoropoulos G: Stem cells in colon cancer. A new era in cancer theory begins. Int J Colorectal Dis 26: 1-11, 2011.

35. Baumann M, Krause M and Hill R: Exploring the role of cancer stem cells in radioresistance. Nat Rev Cancer 8: 545-554, 2008.

36. Eyler CE and Rich JN: Survival of the fittest: cancer stem cells in therapeutic resistance and angiogenesis. J Clin Oncol 26: 2839-2845, 2008

37. Frank NY, Schatton T and Frank MH: The therapeutic promise of the cancer stem cell concept. J Clin Invest 120: 41-50, 2010.

38. Li M, Li JY, Zhao AL and Gu J: Colorectal cancer or colon and rectal cancer? Clinicopathological comparison between colonic and rectal carcinomas. Oncology 73: 52-57, 2007.

39. Chung CK, Zaino RJ and Stryker JA: Colorectal carcinoma: evaluation of histologic grade and factors influencing prognosis. J Surg Oncol 21: 143-148, 1982.

40. Umpleby HC, Bristol JB, Rainey JB and Williamson RC: Survival of 727 patients with single carcinomas of the large bowel. Dis Colon Rectum 27: 803-810, 1984.

41. Kazama Y, Watanabe T, Kanazawa T, Tanaka J, Tanaka T and Nagawa H: Poorly differentiated colorectal adenocarcinomas show higher rates of microsatellite instability and promoter methylation of p16 and hMLH1: a study matched for T classification and tumor location. J Surg Oncol 97: 278-283, 2008.

42. Mulder JW, Kruyt PM, Sewnath M, Oosting J, Seldenrijk CA, Weidema WF, Offerhaus GJ and Pals ST: Colorectal cancer prognosis and expression of exon-v6- containing CD44 proteins. Lancet 344: 1470-1472, 1994.

43. Weg-Remers S, Anders M, von Lampe B, Riecken EO, Schuder G, Feifel G, Zeitz M and Stallmach A: Decreased expression of CD44 splicing variants in advanced colorectal carcinomas. Eur J Cancer 34: 1607-1611, 1998.

44. Lugli A, Iezzi G, Hostettler I, Muraro MG, Mele V, Tornillo L, Carafa V, Spagnoli G, Terracciano L and Zlobec I: Prognostic impact of the expression of putative cancer stem cell markers CD133, CD166, CD44s, EpCAM, and ALDH1 in colorectal cancer. Br J Cancer 103: 382-390, 2010.

45. Horst D, Kriegl L, Engel J, Kirchner T and Jung A: CD133 expression is an independent prognostic marker for low survival in colorectal cancer. Br J Cancer 99: 1285-1289, 2008

46. Kojima M, Ishii G, Atsumi N, Fujii S, Saito N and Ochiai A: Imunohistochemical detection of CD133 expression in colorectal cancer: a clinicopathological study. Cancer Sci 99: 1578-1583, 2008.

47. Li CY, Li BX, Liang Y, et al: Higher percentage of CD133(+) cells is associated with poor prognosis in colon carcinoma patients with stage IIIB. J Transl Med 7: 56, 2009. doi: 10.1186/14795876-7-56.

48. Choi D, Lee HW, Hur KY, Kim JL, Park GS, Jang SH, Song YS, Lang KS and Paik SS: Cancer stem cell markers CD133 and CD24 correlate with invasiveness and differentiation in colorectal adenocarcinoma. World J Gastroenterol 15: 2258-2264, 2009.

49. Huh JW, Park YS, Lee JH, Kim HR, Shin MG and Kim YJ: CD133 mRNA expression and microsatellite instability in colorectal carcinoma. J Surg Oncol 102: 765-770, 2010.

50. Zlobec I, Terracciano L, Jass JR and Lugli A: Value of staining intensity in the interpretation of immunohistochemistry for tumor markers in colorectal cancer. Virchows Arch 451: 763-769, 2007. 